\title{
Read Death Drive through Heart of Darkness
}

\author{
Qiling $\mathrm{Wu}^{1} \&$ Tsingan $\mathrm{Li}^{2}$ \\ ${ }^{1}$ Department of Foreign Languages and Literature, Beijing Normal University, Beijing, China \\ ${ }^{2}$ Institute of Developmental Psychology, Beijing Normal University, Beijing, China \\ Correspondence: Tsingan Li, Institute of Developmental Psychology, Beijing Normal University, Beijing, China. \\ E-mail: tsingan@126.com
}

Received: February 26, 2017 Accepted: March 25, 2017 Online Published: May 30, 2017

doi:10.5539/ells.v7n2p128 URL: http://doi.org/10.5539/ells.v7n2p128

\begin{abstract}
Scholars try to get close to Kurtz and Conrad's inner men to analyze their attitudes towards race through race. However, the author transfers race into human drive to give explanation of Marlow's narrative in Heart of Darkness and further argues that Marlow's narrative has dug deeply into human beings' drive. To change it another way, the journey to the central Africa does not just force Marlow to see primitive Africa, the natives, to meet Kurtz, his madness and evil, it is also a journey to self-discovery or drive-discovery.
\end{abstract}

Keywords: race, death drive, self-discovery

\section{Introduction}

Heart of Darkness by Joseph Conrad is selected as one of the 100 best novels of all time and also "remains one of this century's most enduring works of fiction". Step by step, through Charles Marlow's monologue, readers are brought close to Kurtz, first-class agent with a "noble heart" (p. 75) and leader, whose "soul [is] mad" (p. 66) of natives in Central Africa. The short story raises readers' awareness of colonialism, race, feminism, primitivism, and so on. Among these themes, a lot of critics have paid special attention to race. They are attracted by the vague and complicated comparison between Europeans and Africans. Also, they try to get close to Kurtz and Conrad's inner men to analyze their attitudes towards race through race. Further, they use their theories of race to evaluate Marlow's narrative.

For example, Anthony Fothergill's essay "Cannibalising Traditions: Representation and Critique in Heart of Darkness" explains how literary and scientific observations about Africans, the "Other", were established during the 19th century. Then he moves on to argue that Heart of Darkness "embodies a radically ambivalent tendency in representing the Other" (p. 449). On one hand, Marlow's narrative shows the stereotype of portraying the "savage" (Conrad, p. 6) as "uncivilized" and "primitive". On the other hand, it also questions why these people are seen as "savages" and "enemy". Fothergill's assertion finally goes to be "[Conrad's] representation of the African offers a self-conscious critique of Europeans representations, even to the point of questioning the very basis of such Otherness" (p. 449). According to Fothergill's argument, Marlow's narrative, to certain degree, goes beyond the stereotype figures of Africans and also challenges racism.

However, another essay, "The Problem of the Subject in Africanist Discourse: Conrad's "Heart of Darkness" and Camus' "The Renegade"" written by Mona Fayad, declares that Marlow's narrative does not succeed in escaping the discourse of "binary oppositions of civilized/savage, order/disorder, master/slave" (p. 311). Fayad firstly explains a term, "Africanist discourse", which is firstly dubbed by Christopher Miller to say that Africa is represented as Europe's repressed and dark side. Further, he argues that this Africanist discourse leads to the dehumanization of the other through "depriving him/her of the basis for individuality" (p. 305) and he takes Marlow as an example. Marlow sees the Africans' "restraint" (p. 306) on the ship, which is supposed to be a particularly English virtue while he noticed that it is actually lacking in the Europeans he has met on the river. However, he quickly weakens any possibility of humanizing the Africans, and changes his view of them to animals. From this perspective, Fayad comes to the conclusion that Marlow's narrative is constrained by the stereotype of the portrayal of Africans or the "savage".

Both essays try to evaluate the break and limitation of Marlow's narratives based on race. I agree with both ideas. Marlow's narrative challenges the stereotype portrayal and thought about the "savage" but it is also inevitably limited because of the limitation of Marlow or even Conrad's view, which is due to their background. However, 
instead of taking race (European/African, Civilized/Primitive) as a standard to evaluate Marlow's narratives, I want to transfer race into human drive to give explanation of Marlow's narratives in the Heart of Darkness and I argue that Marlow's narrative has dug deeply into human beings' drive.

\section{Method}

Before analyzing Heart of Darkness, I will talk about the definition of drive from the perspective of psychology. Freud and some other psychologist divided drive into sex drive and self-preservation. The former refers to sexual or reproductive drive; the latter includes hunger, fear and danger and so on. Later Freud changed the way of the previous classification, and divided drive into life drive (Eros), and death drive (Thanatos). The former includes sexual drive and self-preservation, representing a kind of love and construction of power; the latter includes sexual abuse, assault, destruction, self- destruction and so on, representing a kind of hate and destructive force.

Other religious works also present the same psychology especially death instinct. For example, Romans 7:18 says "For I know that in me, that is, in my flesh, nothing good dwells; for to will is present with me, but to do the good is not." Romans 7:20 says "But if what I do not will, this I do, it is no longer I that do it but sin that dwells in me." Also as Aurelius Augustin said in Confessions "I was produced in crime, in the embryo I was guilty, my God, where and when will the servant be innocent?" He defines this sin or death drive as "original sin". According to the Holy Bible: recovery version, Adam was born without any sin and there is "life drive" at the beginning of the world. However, because Adam ate the fruit from the tree of the knowledge of good and evil, Satan, as death drive, entered into man and caused him to fall. Satan's evil thought, feeling, and will, thus, were injected into man's soul, which includes mind, emotion, and will. Because of this sin, fallen man was constituted a sinner (Rom. 5:19) and became a victim of death (Rom. 5:12b, 14a).

Also to explain better about Kurtz's different behaviors in Europe and Africa, which I will explain later, another thing that we need to note is that drive needs to be triggered. For example, Freud argues that infantile sexuality is inevitable, because sexuality is life drive, regardless of whether the child was born, sexuality is always there. It's just the time to trigger the life instinct that differs. In the case of infantile sexuality, the time to trigger is when the infant's tongue touches his mother's nipples. The trigger is proven when the child sucks fingers and plays reproductive organs to get sexual pleasure. Once such kind of drive is not satisfied, like the need for amino acid and calcium, the deficiency of drive triggers can cause disease. For example, Freud said if infants don't get sexual satisfaction, then this is likely to lead to sexual perversion in the future.

\section{Discussion}

In the next part of the essay, I will take Heart of Darkness as an example to specifically explain death drive and show that Marlow's narrative digs into human beings' interiors, death drive, profoundly and correctly. First of all, Marlow himself treats the journey as a process to self-discovery, which is directly connected with self or drive instead of race. In "The Journey Within", according to Albert J. Guerard, Heart of Darkness is about Marlow's physical and psychological journey to the Congo. He says, "Marlow reiterates often enough that he is recounting a spiritual voyage of self-discovery" (p. 329) and "He returns to Europe a changed and more knowing man" (p. $329)$.

I do agree with Guerard that the journey to the central Africa does not just force Marlow to see primitive Africa, the natives, to meet Kurtz, his madness and evil, it is also a journey to self-discovery or drive-discovery. In Heart of Darkness, for example, the jungle is a "thing monstrous and free" (Conrad, p. 36) and the African natives "howled and leapt and made horrid faces" (Conrad, p. 36). In Marlow's eyes, the journey is like "traveling back to the earliest beginnings of the world" (Conrad, p. 33). Now he focuses on the death drive reflected by the environment but he is not aware of the source of his repression, which is death drive. For him, he tries to convince himself that his unease is not from himself but from his surroundings.

If Marlow is successful in convincing himself of the horrible effect of surroundings instead of the death drive in his heart, then, meeting Kurtz definitely breaks his illusion and brings him to the reality that death drive is within every human being. Actually, before Marlow meets Kurtz, he has already touched the reality. For example, Marlow is thrilled by the thought that "their (the natives) humanity-like yours - the thought of your remote kinship with this wild and passionate uproar. Ugly (Conrad, p. 36). He connects himself to this "terrible frankness" of the natives, admitting that certain evil or death drive is in his own heart. Thus, he feels lucky when he has to be occupied by the work and this helps him hide the "inner truth" (Conrad, p. 36). Many other psychological explorations are also mentioned in the story like saying the distinguished men on the Nellie perform "monkey tricks", "the word 'ivory' rang in the air" (Conrad, p. 35), the cruelty of imperial enterprise or even Marlow's desire to continue looking for Kurtz all prepares Marlow to turn from exteriors to interiors. 
Marlow's real self-discovery or death drive discovery really begins after he meets Kurtz. To make this point clear, we need to note that death drive is within everyone, so Kurtz does not bring darkness to Africa, nor does Africa make Kurtz dark. Death drive is in Kurtz's and also Africans' hearts. However, as I have stated, death drive needs to be triggered. When Kurtz is in London, he has few chances to be exposed to situations that can trigger death drive. However, in Africa, a primitive continent, where the natives live according to their drives, death drive in Kurtz gets a great chance to be triggered. To prove this point, I will cite several sentences from Heart of Darkness:

He had taken a high seat amongst the devils of the land - I mean literally. You can't understand. How could you? - with solid pavement under your feet, surrounded by kind neighbors ready to cheer you or to fall on you, stepping delicately between the butcher and the policeman, in the holy terror of scandal and gallows and lunatic asylums - how can you imagine what particular region of the first ages a man's untrammeled feet may take him into by the way of solitude - utter solitude without a policeman — by the way of silence, utter silence, where no warning voice of a kind neighbor can be heard whispering of public opinion? These little things make all the great difference. When they are gone you must fall back upon your own innate strength, upon your own capacity for faithfulness (Conrad, p. 48).

According to the text, Kurtz's death instinct is triggered because he lives far away from the so-called civilization, where people are "in the holy terror of scandal and gallows and lunatic asylums," which promotes triggering life drive and decreasing the appearance of death drive. Further, according to Marlow's narrative, the drive is indeed triggered. First of all, Kurtz has the wish to travel to Africa to complete great mission of "humanizing, improving, and instructing" (Conrad, p. 33). However, his obsession takes over his original purpose. The ambition to get more ivory helps him taste the power among the natives in the jungle and the taste of the power triggers his death drive, which is heart of darkness. Thus, he begins to be mad, flabby devils has "got into his veins, consumed his flesh" (Conrad, p. 48), and he becomes "an impenetrable darkness", who is "lying at the bottom of a precipice where the sun never shines" (Conrad, p. 68). A collection of heads are put on the fence posts around the station to show his authority among the natives. He becomes even more obsessed with ivory and Marlow even says his head "was like a ball - an ivory ball" (Conrad, p. 48). He was trapped by the jungle, the center of darkness and even when he was nearly dying, he crawled on all- fours toward the native camp to finish his immense plans. Also compared with his original plan to bring civilization to the natives, he dies holding the belief that the Company should simply "Exterminate all the brutes" (Conrad, p. 46)! "The horror, the horror" (Conrad, p. 69) becomes his summary of his experience in the jungle and finally he sees clearly about the power of death drive in him.

Kurtz is a living answer to Marlow's self-discovery. Marlow has the confusion after he sees the Africans"They were dying slowly - it was very clear. They were not enemies, they were not criminals, they were nothing earthly now" (Conrad, p. 17). He seems afraid to admit that actually he could be like the Africans, being controlled by primitivism, darkness or death. In "Marlow's Descent into Hell", Lillian Feder argues that "as Marlow goes deeper and deeper into the jungle, the image of hell is intensified, until finally hell and the Congo are equated" (p. 289). Marlow is led by Kurtz into the depths of the jungle where fiendish rites take place and he allows himself to "sink to the lowest possible depths of evil" (p. 290). In Heart of Darkness, through Kurtz, Marlow realizes that in all men including himself there is death drive. That is why when he enters into the home of Kurtz's intended, he feels that he carries with him the "gloom" and "the beating of a heart-the heart of a conquering darkness" (Conrad, p. 597). Thus, "the horror, the horror" is also the answer of Marlow's self-discovery or death drive discovery.

In this essay, I point out that Marlow's narrative, the process of self-discovery, is much more than the matter of going beyond stereotype figures of Africans or challenging racism. Marlow's narrative digs deeply into human beings' drive especially the death drive by describing his confusion towards self and the other, the Africans, dehumanization, and so on. From the perspective of exploring human drive, Heart of Darkness offers us a good platform to think about good and evil, and even to think about the mystery of human life. It is a good portrayal of human beings and deserves reading and evaluating.

\section{Acknowledgments}

I would like to express my sincere gratitude to Amit R. Baishya at the Univeristy of Oklahoma. He took care of me when I was in America, and he is my inlightening teacher of writing academic papers. I feel especially grateful to my professor Wang Qiang at Being Normal University for her support of my learning in the past semester. Finally, but not least, I want to thank my parents, my brother Michael and my sister Iva. Their pride in me has enhanced my confidence to get through all the difficulties and succeed in the end. 


\section{References}

Bible, H. (2003). Recovery Version. Anaheim, CA: Living Stream Ministry.

Conrad, J., \& Armstrong, P. B. (2006). Heart of Darkness: Authoritative Text, Backgrounds and Contexts. Criticism.

Fayad, M. (1990). The Problem of the Subject in Afiricanist Discourse: Conrad's "Heart of Darkness" and Camus" "The Renegade". Comparative Literature Studies, 27(4), 298-312. Retrieved from http://www.jstor.org/stable/40246768

Feder, L. (1955). Marlow's Descent into Hell. Nineteenth Century Fict, 9(4), 280-292. https://doi.org/10.2307/3044393

Fothergill, A. (1996). Cannibalising Traditions: Representations and Critique in Heart of Darkness. Under Postcolonial Eyes: Joseph Conrad After Empire, 93-107.

Guerard, A. J. (1958). The journey within. Heart of Darkness, 326-336.

Miller, C. L. (1985). Blank darkness: Africanist discourse in French. Chicago: University of Chicago Press.

\section{Copyrights}

Copyright for this article is retained by the author, with first publication rights granted to the journal.

This is an open-access article distributed under the terms and conditions of the Creative Commons Attribution license (http://creativecommons.org/licenses/by/4.0/). 